\title{
HATEZER ÉV RÉTEGSORA \\ Előzetes jelentés az egykori Óbudai Szeszgyár (Buszesz) területén végzett megelőző feltárásról
}

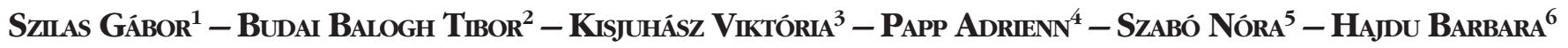
Magyar Régészet 9. évf. (2020), 4. szám, pp. 1-12. https://doi.org/10.36245/mr.2020.4.6

Árpád-kori kökemencés veremházak, római kori téglasírok és közfürdő, középső bronzkori épületek omladékai, kora bronzkori temetö, késö rézkori agyagnyerö komplexumok. A több méter vastag rétegsorban egymás alatt jelentkezö sok ezer régészeti jelenség, valamint csaknem ezer láda leletanyag csupán az érem egyik oldalát jelenti. A folyamatosan zúgó gépek, a betontörés fülsüketitö robaja és porfelhője, a HÉV ütemes hangja, külföldi épitömunkások moraja és szük régészeti határidők alkotják az ellenpólust. Az egykori óbudai szeszgyár területén csaknem három éve tartó próba- és megelözö feltárások során a városi régészet csaknem minden ismert elemével szembesültünk, ugyanakkor tisztában vagyunk azzal is, hogy a nehézségek ellenére egyedi, különleges és talán megismételhetetlen lehetöség részesei lehetünk. Kutatási területünk ugyanis a római kori katonavárost és a középkori Óbudát lefedö történeti városmagok peremén helyezkedik el, a vizsgált lelöhelyrész kiterjedése pedig nem csak vertikális, hanem horizontális értelemben is tekintélyt parancsoló. A terepmunka rendkivül informativ idöszakát követöen remélhetöen mihamarabb kezdetét veszi a feldolgozás fázisa, melynek eredményeképpen lépésröl lépésre haladva érthetjük meg e különleges hely jelentöségét, ahol mostanáig az emberi jelenlét hatezer esztendöt átölelö rétegsora húzódott.

\section{A HELY SZELLEME - A TERÜLET KÖZELMÚLTJA ÉS KUTATÁSÁNAK TÖRTÉNETE}

A Budapest III. kerületében található Bogdáni út - Folyamőr utca - Laktanya utca - szentendrei HÉV vonal által határolt terület Óbuda frekventált, központi részének számít, amely arany betűkkel írta be magát a föváros kiegyezést követően fellendülő iparosításának történetébe. Itt, ezen a telken alapította ugyanis 1867 ben Deutsch Jakab azt az ipari szeszt előállító gyáregységet, amely Leipziger Vilmos irányításával a századfordulóra az ország legnagyobb szesz- és ecetgyártó üzemévé nőtte ki magát (1. kép). A gyár területén folyó ipari tevékenység a folyamatos átalakításokat követően, csak a 2010-es évek elején szünt meg; a terület új tulajdonosa 2016-ban kezdte meg a meglévő gyárépületek bontási munkáit. Mindezek fényében cseppet sem meglepő, hogy a szóban forgó területről már mintegy 150 éve kerülnek elő eltérő forrásértékkel bíró régészeti leletek, így a telek régészeti érintettsége szakmai berkekben már a 2017. évi próbaásatást megelőzően is közismert ténynek számított (GYURICZA 2008, 2-5).

A többkorszakos lelőhely öskori emlékeire vonatkozó első adatok még a 19. század utolsó harmadából

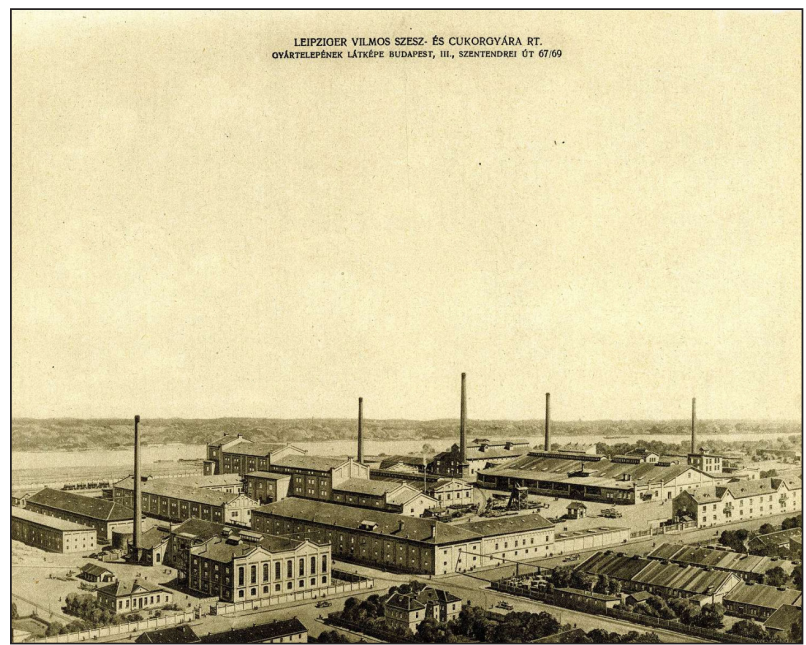

1. kép. Leipziger Vilmos Szesz-és Cukorgyára Rt. gyártelepének látképe 1930-ból (Fövárosi Szabó Ervin Könyvtár, lelt. sz.: bibFSZ01472071)

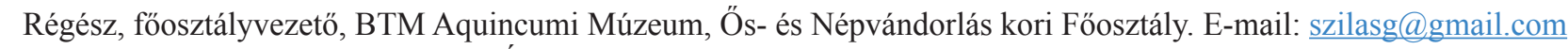

Régész, BTM Aquincumi Múzeum, Ókortörténeti Főosztály. E-mail: budaibalogh@yahoo.com

Régész, BTM Aquincumi Múzeum, Ös- és Népvándorlás kori Főosztály. E-mail: kisjuhaszv@gmail.com

4 Régész, BTM Aquincumi Múzeum, Középkori Főosztály. E-mail: adry.papp@gmail.com

Régész, ELTE BTK Régészettudományi Intézet. E-mail: szabonori91@gmail.com

Régész, BTM Aquincumi Múzeum, Ókortörténeti Főosztály. E-mail: hajdu.barbara@aquincum.hu
} 


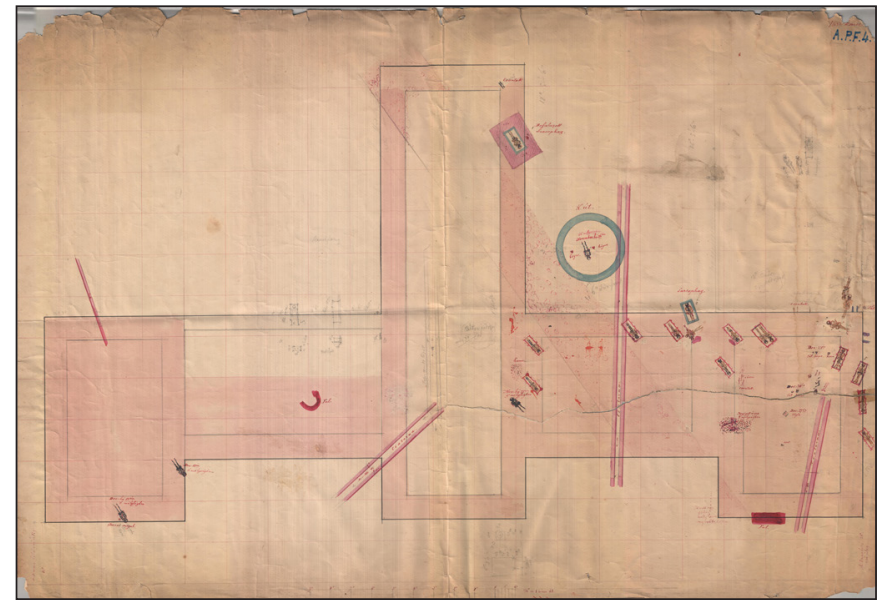

2. kép. A keleti temetö elsöként feltárt sírjai a későbbi „,központi csarnok” területén (Rómer Flóris 1868. évi feltárása; Zsigmondy Gusztáv összesitö akvarellje. Budapesti Történeti Múzeum Aquincumi Múzeuma, Rajztár)

származnak, és bár a későbbi leletmentések, feltárások többnyire a római kori települési viszonyokat vizsgálták, az így felszínre kerülő késő rézkori, késő bronzkori, kora és késő vaskori leletek a terület intenzív őskori használatára utalnak (HAVAs 1892, 18; NAGY G. 1904, 111; NAGY L. 1937, 261; KABA 1984, 457, no. 2; KöSZEGI 2000, 64, 81).

A gyárépítési munkák kezdetén (1868) láttak napvilágot az első római kori sírok (RÓMER 1868, 41-44, 65-68, 91-94; 2. kép) is. Ezek folyamatos elökerülése (KuZsInszKY 1897a, 102; KUZSInSZKY 1897b, 403) miatt rövid időre még annak gyanúja is felmerült, hogy a Szeszgyár teljes kiterjedésében az aquincumi katonaváros északi temetőjének területére esik (NAGY L. 1937, 266). A későbbiek során aztán a telephely felezővonalától délre mind gyakrabban kerültek felszínre a katonaváros lakóházai, fürdőre utaló épületmaradványai, úttest- és csatornarészletei (NAGY L. 1942, 359, 363; SzILÁGYI 1955, 403; KabA 1976, 417, no. 86; Póczy 1983, 267).

A népvándorláskori területhasználatot szórványként gyüjtött, késő avarkori kerámiaedények alapján feltételezték (NAGY M. 1998, 39-40: FO 16), miközben a középkorkutatás a feltárássorozat 2017. évi megindítása előtt ugyancsak szórványleletek alapján (NAGY T. 1973, 212; FeHÉR, ÉRY \& KrALOVÁNSZKY 1962, 25, no. 110) 10. századi temetőt sejtett a Szeszgyár területén.

Mindezen tudás birtokában 2017-ben kezdődött és napjainkban is zajlik a terület legújabb és egyben legátfogóbb kutatási időszaka. A telekre tervezett multifunkcionális lakópark építkezéséhez kapcsolódó ásatássorozat első felvonásaként Budai Balogh Tibor által vezetett próbafeltárás pontosította a lelőhely belső időrendjére, az épített emlékek területi eloszlására vonatkozóan eddig meglévő ismereteinket, és a későbbi kutatások tervezéséhez elengedhetetlenül fontos információkat nyertünk a terület belső rétegvi- 
szonyairól, bolygatottságának mértékéről is (BUDAI BALOGH 2020).

Ezt követően 2018 szeptemberében vette kezdetét - elöbb Havas Zoltán, majd Szilas Gábor vezetésével - egy megelőző feltárás-sorozat, amely az építési telek északról dél felé haladó beépítési üteméhez igazodva folyik, közvetlenül a kivitelezés előtt. A 2020 decemberéig befejeződő, három nagyobb ásatási szakaszt magában foglaló kutatás során mintegy 1 ha-os területen kilenc régészeti korszak legalább tizennégy periódusához tartozó (3. kép) három és félezer régészeti jelenség feltárását végeztük el (4. kép), és a munka csaknem ezer láda régészeti leletanyagot eredményezett. A jóval az átlag feletti intenzitást és komplexitást mutató lelőhely kutathatóságának szempontjából fontos kiemelni, hogy a próbafeltárás eredményei alapján csupán az építési telek déli felében számolhatunk a sürü római városi beépítéssel összefüggésben megtartásra érdemes római kori épített emlékekkel. Ezzel szemben az északra eső felületek esetében lehetőségünk nyílt és nyílik a teljes, az újkori bolygatások ellenére viszonylag épen megőrződött régészeti rétegsor teljes, maradéktalan feltárására. Kutatásunk emellett horizontális kiterjedésében is mértékadó lehet, hiszen ez utóbbi területrészen 2022-ig várhatóan mintegy $15000 \mathrm{~m}^{2}$-nyi, csaknem összefüggő felület vizsgálatára nyílik lehetőség. Ezzel együtt ugyanakkor munkánk során jelentős módszertani kihívással is szembesülünk, hiszen míg méretében, valamint pénzügyi, időbeli kereteit tekintve ásatásunk inkább a nagyfelületü feltárások kategóriájába sorolható, ennek keretein belül egy, a történeti városmagokra

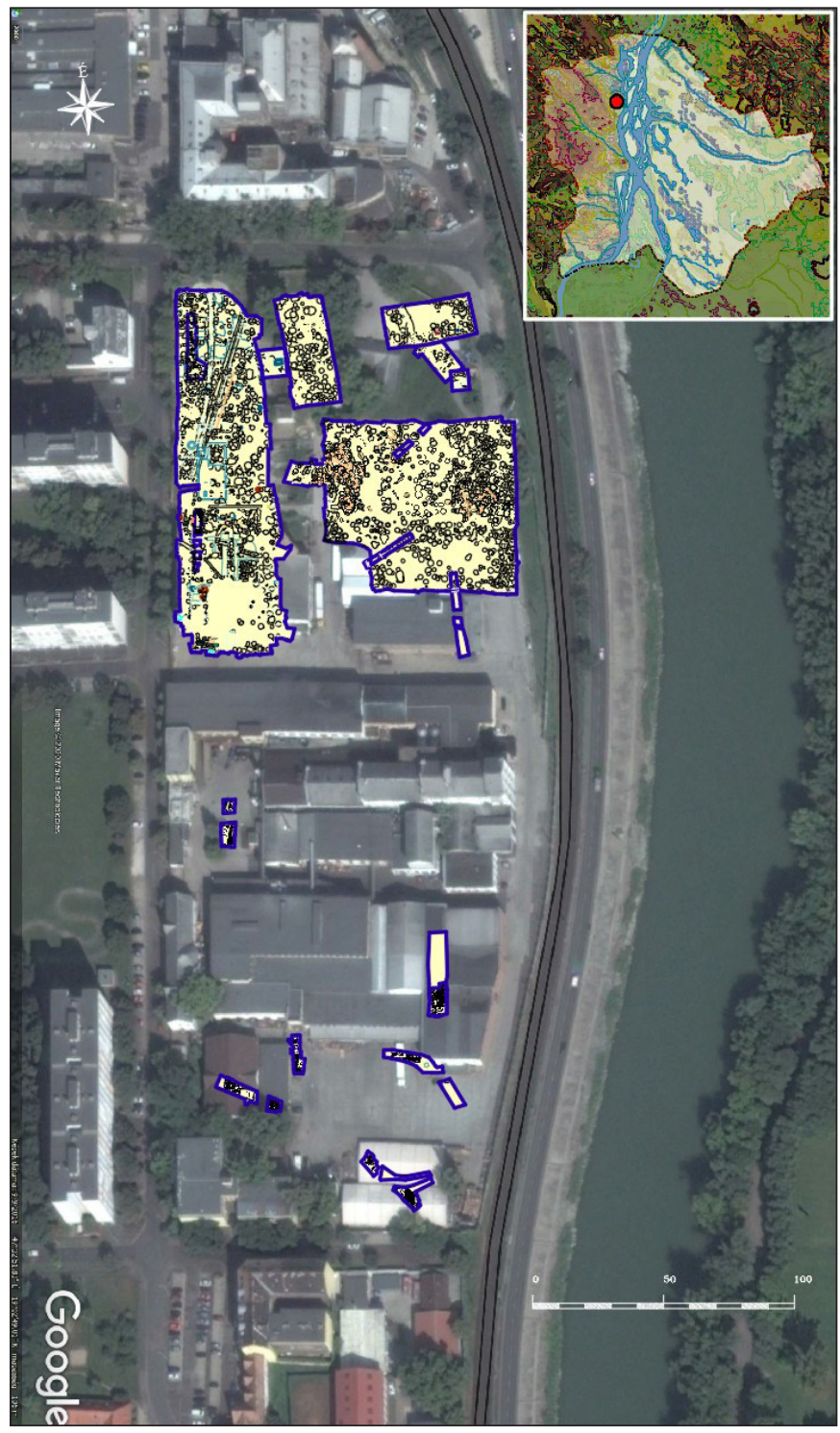

4. kép. A 2017-2020-as kutatások összesitő alaprajza, a gyártelek területére vetítve (geodézia: Fábián István, Kovács Tibor, Juhász Gergely) jellemző vastag rétegsort mutató lelőhely kutatását kell teljeskörüen és szakmailag is kielégítő módon elvégeznünk. Mindezt természetesen csak egy hatékonyan együttmüködő csapat munkája révén valósíthatjuk meg, amelynek tagjai a régész kollégák és régésztechnikusok mellett a terepi helyzetre gyorsan reagáló földmérök és a tudományos feldolgozáshoz kapcsolódó helyszíni vizsgálatokat (drónfotózás, természettudományos mintavételek stb.) végző munkatársak is. ${ }^{7}$

\section{A LELŐHELY GEOMORFOLÓGIAI, ŐSVÍZRAJZI ÉS RÉTEGTANI VISZONYAI}

Az óbudai Duna-partszakaszra vonatkozó, és egyre kiterjedtebb környezetrégészeti, geomorfológiai kutatásaink (SzILAS et al. 2019) nyomán kijelenthető, hogy területünk egyike a Budakalászi-Óbudai-öblözet

\footnotetext{
Itt fejezzük ki köszönetünket Lamm Flóra régésznek, Alfred Falchetto, Barna Ferenc, Kelemen Zsófia, Langer Dániel, Solnay Eszter, Schmidt Nikolett, Szabó Balázs, Tóbel-Domonkos Tícia régésztechnikusoknak, valamint Kangyal Orsolya és Lajtos Tamás rajzolóknak, Kovács Tibor, Fábián István és Juhász Gergő geodétáknak, akik a terepi dokumentációs munkákban voltak nagy segítségünkre. Külön köszönet illeti Sándor Lajos müszeres leletfelderítőt az általa talált számtalan értékes fémtárgyért, Rupnik Lászlót (ELTE) a drónfelvételek készítéséért, Vicze Magdolnát, Kovács Gabriellát (Matrica Múzeum Százhalombatta) a mikromorfológiai, Viczián Istvánt és Balogh Jánost (ELKH FKI) az üledékföldtani és talajtani mintavételezés elvégzésért, valamint mindenkit, aki akár csak rövid időre is, de tevékenyen részt vett a feltárásban.
} 


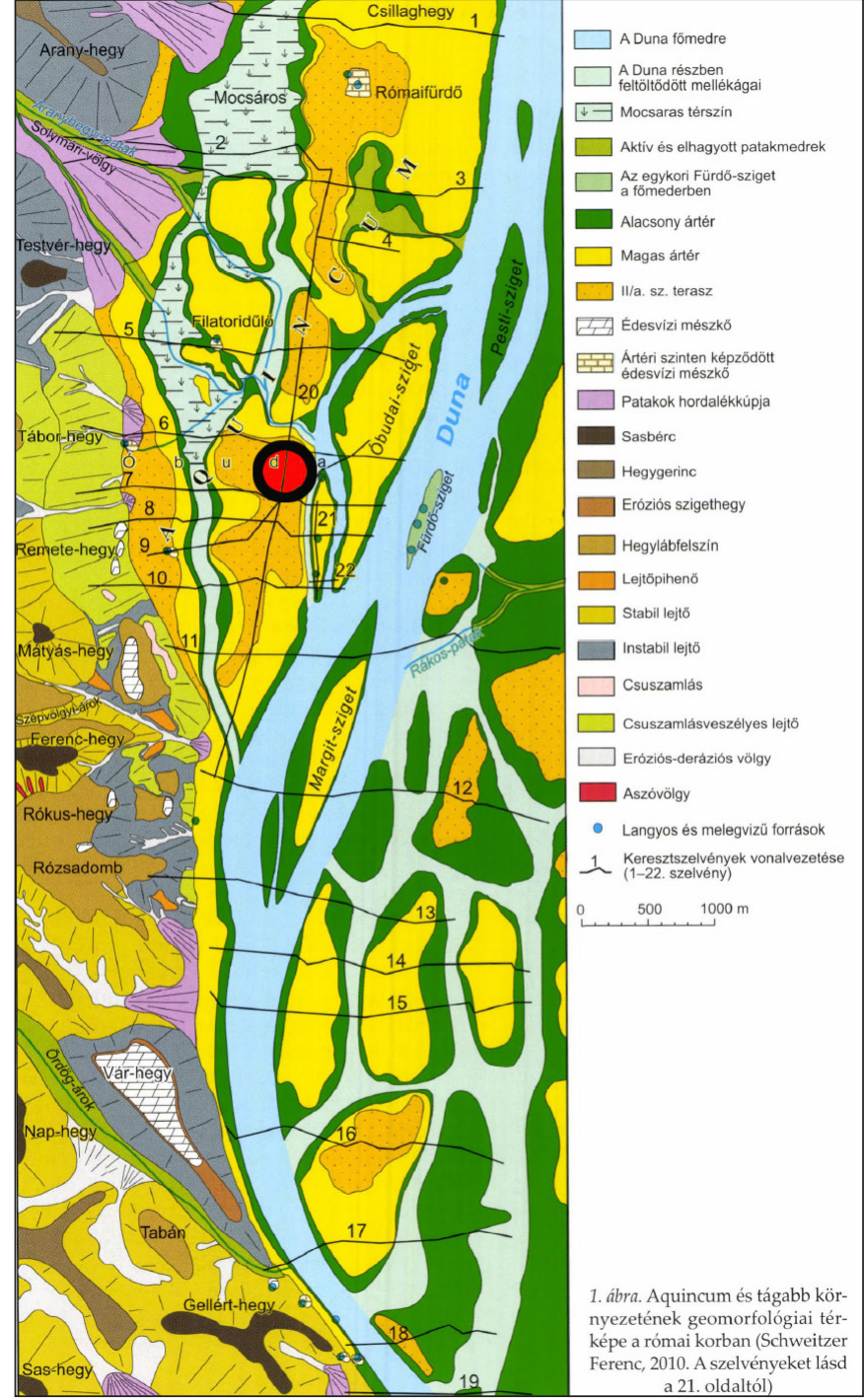

5. kép. A Budakalász-Óbudai öblözet geomorfológiai térképe a feltárás helyével

(H. KÉRDÖ \& SCHWEITZER 2010, 1. ábra felhasználásával)

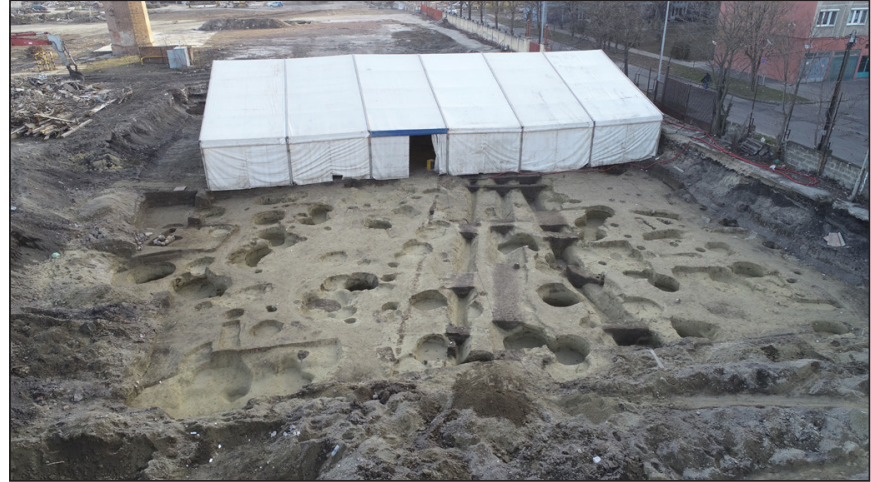

6. kép. 2018 telén készitett légifelvétel a lelőhely nyugati, magasabban húzódó sávjában nyitott feltárási szelvényröl (fotó: Rupnik László)

mikrorégió legkedvezőbb megtelepedési feltételeket kínáló térségeinek. Egykori felszínét részben a Duna pleisztocén bevágódása nyomán formálódó, 102,8 mBf átlagmagasságú, ármentes terasz felszíne alkotja. Kiváló közlekedésföldrajzi helyzetét a föág és az Aranyhegyi-patak egykori, a Filatorigáthoz lokalizált torkolatának viszonylagos közelsége erősítette, a vele határos föág-szakasz szigetekkel (Kisés Nagy-Óbudai-sziget) tagolt zónája pedig a hely védelmi adottságát, gazdasági potenciálját növelte (5. kép).

A szükebb értelemben vett kutatási terület rétegviszonyait és a területhasználat tér- és időbeli paramétereit alapvetően két, eltérő jellegü természetföldrajzi-morfológiai elem jelenléte határozza meg. Míg a nyugati $30 \mathrm{~m}$ széles sávban a Duna ún. II/a terasz maradványát alkotó löszös, homokos területet, ettől keletre egy eleinte meredekebben, majd enyhébben lejtö, kisebb egyenetlenségeket mutató, agyagos-löszös altalajon képződő ún. magas árteret (I/b terasz) találunk. Ezzel összefüggésben elöbbi területén jellemzően 40-60 cm vastag kultúrréteget dokumentáltunk (6. kép), utóbbi zónájában - hasonlóan a békásmegyeri partszakaszon tapasztaltakhoz - a rétegolló kinyílásával 1,5-2 m vastagságú, nagyobb horizontális és kisebb lokális szinteket egyaránt mutató régészeti rétegsort rögzítettünk (7. kép).

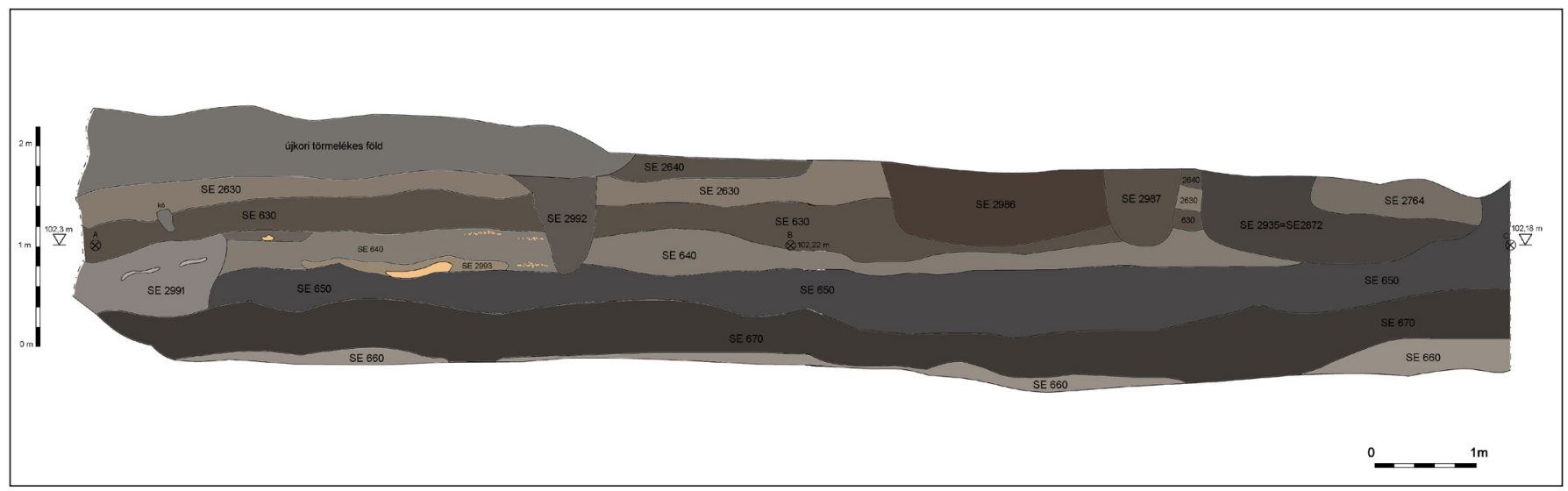

7. kép. Települési rétegek a „2D”felület nyugati tanúfalában. Metszetrajz (rajz: Kangyal Orsolya) 


\section{A FELTÁRÁSOK SORÁN ISMERTTÉ VÁLT RÉGÉSZETI KORSZAKOK}

A kutatás jelenleg még a terepi dokumentálás fázisánál tart, így az eddig megszerzett információk elsősorban topográfiai jellegü következtetések levonását engedik meg, ugyanakkor egyes jelenségcsoportok láthatóan már most túlmutatnak lelöhelyünk közvetlen jelentőségén.

\section{Az öskor évezredei}

A terület legkorábbi emberi megtelepedésére ezidáig csak közvetett adatokkal rendelkezünk. A magasártér keleti harmadában jelentkező természetes eredetü üledékgyüjtő mélyedésbe másodlagosan bemosódó középső neolitikus leletanyag (csípett díszes, benyomkodott bütykös töredékek a Dunántúli Vonaldíszes Kerámia kultúrájának kottafejes és Zselíz időszakából, ${ }^{8}$ Kr. e. 5300-5000/4950) egy ilyen korú telep viszonylagos közelségére utal. Területünktől északra, a Csillaghegy-Békásmegyer partszakasz újkőkori települési hálózata viszonylag jól ismert (SzILAS \& VIRÁG 2017,23-24), és a területtel szomszédos dunai szigetvilág neolitikus területhasználata is lokalizálható (KÉRDŐ \& VIRÁG 2006).

A késő rézkori Baden-kultúrának (Kr. e. 3500-3000) döntően a mélyebb, keleti térszín vastag, fekete agyagos humuszrétegében megtalált, kisebb-nagyobb gödörkomplexumai, hulladékgödrei egy nagy kiterjedésü, a part mentén hosszan elnyúló település részét képezik, melyet a friss terepi megfigyelések alapján északi irányban egészen a Filatorigát magasságáig követni tudunk. ${ }^{9}$ A települési gödrök betöltéseiböl a természeti erőforrások intenzív kihasználásra utaló, nagy mennyiségü kagyló és halpikkely maradvány mellett egy gödörbe helyezett ép szarvasmarha váz került elö, ami a korszakból több helyről ismert rituális cselekménysor maradványaként értelmezhető. Hasonló nagy kiterjedésü település ismert a békásmegyeri partszakaszról is (LAmM \& SzILAS 2020, 19-26, ENDRŐDI 2002).

Általánosságban kijelenthető, hogy a bronzkor időszaka mutatja a terület legintenzívebb öskori használatát, melyre a nagyszámú települési objektum mellett a csaknem egy méter vastagságban képződött, járószinteket, épületomladékokat tartalmazó kultúrréteg utal.

A kora bronzkor időszakában itt megtelepedő Harangedény-Csepel csoport (Kr. e. 25002200/2100) településrészlete és a vele összefüggö, tőle keletre, a Dunához közelebb húzódó vegyes rítusú temető (8-9. kép) képviseli területünkön a

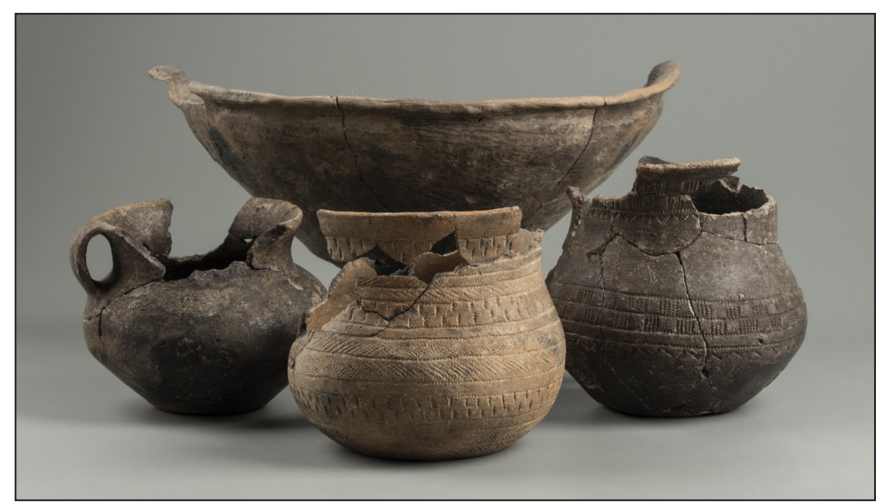

8. kép. A kora bronzkori Harangedény-Csepel csoport sirjának mellékletei (fotó: Szilágyi Nóra, Budapesti Történeti Múzeum Aquincumi Múzeuma)

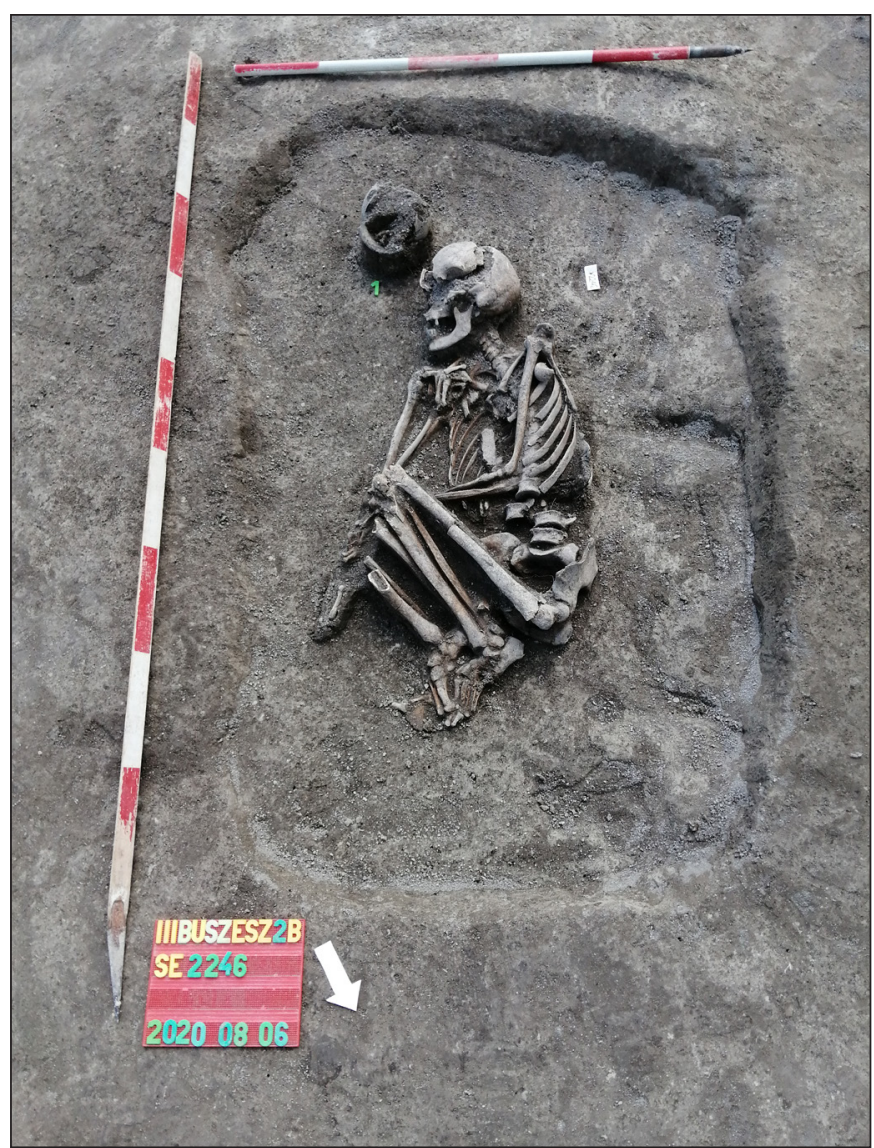

9. kép. A kora bronzkori Harangedény-Csepel csoport zsugoritott csontvázas temetkezése (fotó: Kisjuhász Viktória)

M. Virág Zsuzsanna szíves szóbeli közlése.

9 Budai Balogh Tibor ásatása, 2017. 
legkomplexebb őskori települési struktúrát. A korszak rendkívül sủrü településhálózatára utal, hogy a területünktől északra elterülő folyóparti zónában is jól láthatóan folytatódik az e korszakba sorolható településekből és temetőkből álló láncolat (Graphisoft Park: ENDRŐDI 2001). A település méhkas alakú tárológödrei melletti számos oszlopsor és épületomladék esetleges kora bronzkori oszlopszerkezetes felépítményként való azonosítása azonban csak a leletanyag részletes feldolgozása során lesz lehetséges. A telepjelenségek között kivételesnek számít egy különleges, négyzetes alaprajzú, rituális kontextusokat mutató beásás, mely egyedi rétegsorával, leletanyagával és a benne elhelyezett kutyavázakkal szoros kapcsolatot mutat egy hasonló kialakítású áldozati gödörrel, amit 1988-ban Szigetszentmiklós-Üdülösoron tártak fel (ENDRÖDI 1992, 87, 98, 112, 6. kép 100).

A teljes kutatási területen a késő Nagyrév / kora Vatya időszaktól a késő Vatya / Koszider periódusig (Kr. e. 2200/2100-1400) kimutatható középső bronzkori területhasználat egy önálló, a fekete őshumuszt fedő hamus-faszenes, épülettörmelékes réteghez kapcsolódik, amely jól mutatja a terület jelentőségét a korszakban. Az ebben jelentkező in situ jelenségek és az ebből induló beásások jellegéből és a leletanyag minőségéből (10. kép) világosan látszik, hogy egy, a Duna menti Vatya lelöhelyekhez hasonló, több hektárra kiterjedő horizontális település központi zónájában vagyunk. A munkaterület északkeleti részén rábontással is bővített $19 \times 8$ m-es felületen egyedülálló lehetőségünk nyílt egy felmenő falú, a Vatya-kultúra kései fázisára keltezhető

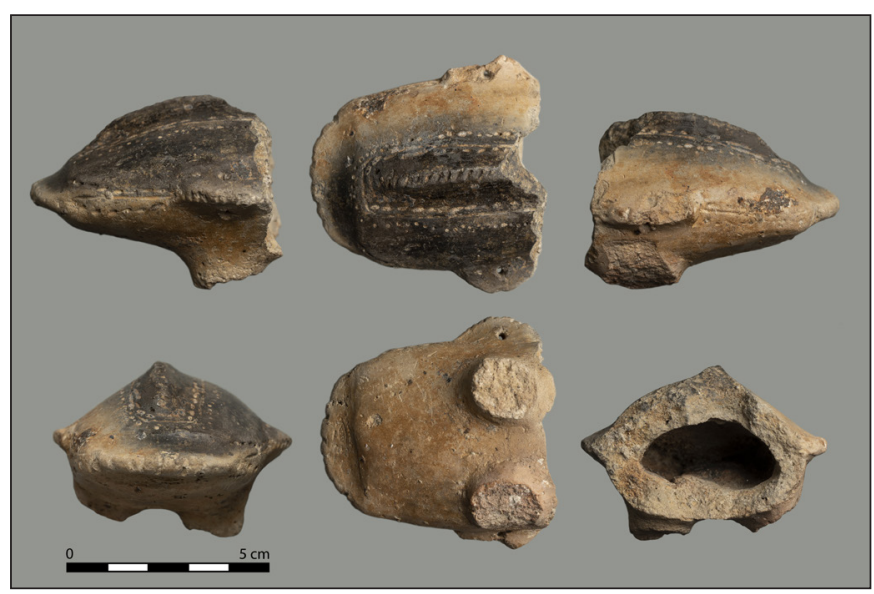

10. kép. Középsö bronzkori, madár alakú csörgö töredéke (fotó: Szilágyi Nóra, Budapesti Történeti Múzeum Aquincumi Múzeuma) többperiódusú épületegyüttes feltárására. A mintegy negyven centiméter vastagságban jelentkező épületomladék bontása során dokumentálni tudtuk a tetőzet és az oldalfalak maradványait, alattuk a házak többszörösen megújított padlószintjeit, tüzelöhelyek, egy-

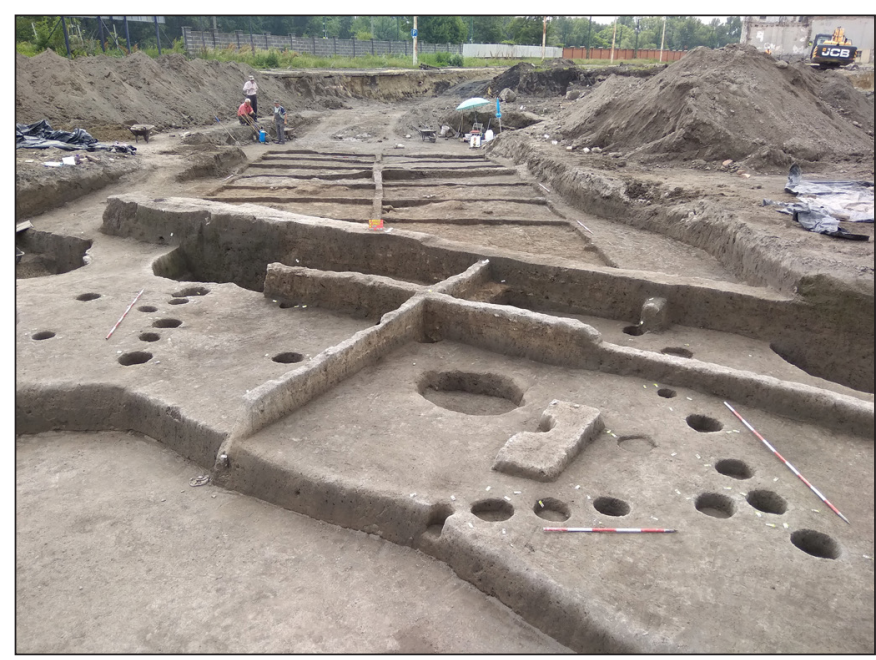

11. kép. Középső bronzkori cölöpvázas épület feltárás közben (fotó: Szilas Gábor) kori berendezési tárgyak nyomait, a fekürétegbe mélyülve pedig szépen kirajzolódott a tetőzetet támasztó és a falszövetet alkotó gerendák oszlophelyeinek struktúrája is (11. kép). E korszakból hasonló jellegü megfigyelésekre ezidáig csak a kultúra központi, erődített, többrétegü tell telepein volt lehetöség (Bölcske: Poroszlai 1992, 144, Százhalombatta: VICZE 2013), az ún. sík telepek építészetére vonatkozóan nagyon kevés ismeretanyaggal rendelkezünk. A ház betöltéséböl archeobotanikai, pollen- és foszfátanalízis céljából szisztematikusan gyüjtött nagyszámú földminta vizsgálata és - a százhalombattai Matrica Múzeummal való együttmüködés keretében - a padlók anyagából vett mikromorfológiai minták kiértékelése mellett az épületek építészettörténeti rekonstrukcióját is szeretnénk elvégezni.

Az épületekre utaló nyomok mellett egy további, igen érdekes telepjelenséget is sikerült megfigyelnünk: a lelöhely több pontján, összesen hat esetben nagy mennyiségü, több rétegben egymásra pakolt kerámiatöredékeket tartalmazó gödröket tártunk fel (12. kép), melyek a leletanyag mennyiségi mutatója mellett az edények funkció szerinti összetétele és a rajtuk látható másodlagos égésnyomok miatt is (deformált, felhabzott felület) figyelemre méltóak. Az említett hat esetet megvizsgálva egyértelmüen megfigyelhető a tárolóedények dominanciája. Az urna alakú edények 


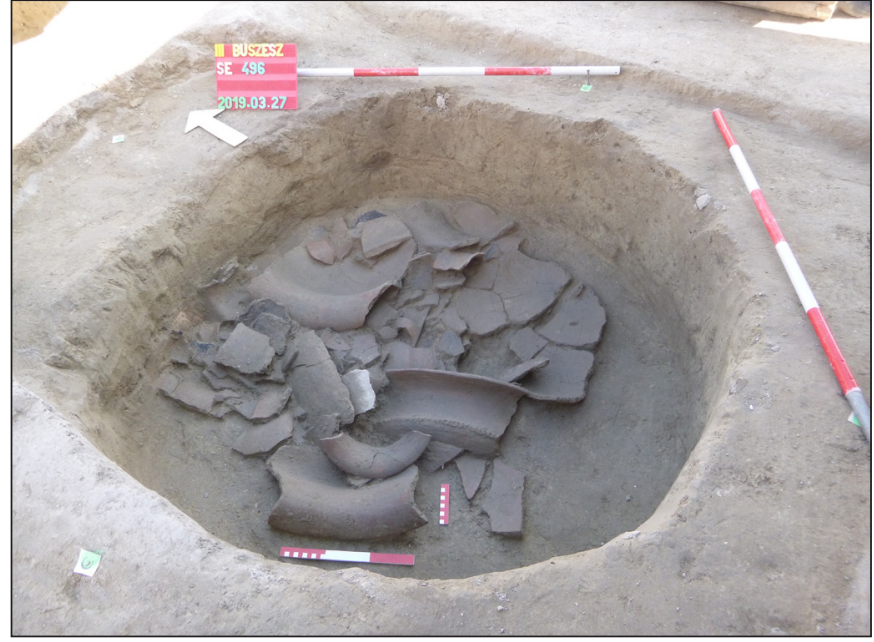

12. kép. Középső bronzkori edénydepó utolsó bontási fázisa (fotó: Szilas Gábor)

és mély tálak mellett belül bütykös, bordázott, durvított felületü, tejtermékek vagy alkoholos italok erjesztésére szolgáló pácoló edények töredékei is elöfordultak bennük. A jelenség különleges, de nem teljesen egyedi, hiszen hasonló szituációban kerültek elő edények Budajenő - Hegyi-szántók középső bronzkori sík településén is (GuCSI \& SzABÓ 2018). A leletegyüttesek minden bizonnyal tudatos döntés következtében kerültek éppen így a gödörbe, így véleményünk szerint a bronzkor teljes időszakában megfigyelhető edénydeponálás esetével állunk szemben. Ez a szokás a leletek összetétele és elhelyezkedése szempontjából igen változatos képet mutat, és okai korszakonként és kulturális közegenként eltérőek lehetnek (KALla, RACZKY \& SzABÓ 2013, 24). Ugyan a középső bronzkor edénydepói között főleg bögrékből álló együtteseket tartanak számon (SchreIBER 1967, 49; KovÁcs 1978, 221; P. Fischl, KISS \& KULCSÁR 1999, 77), az utóbbi évek nagy felületü feltárásai rávilágítottak, hogy a településeken a tárolóedények késő bronzkorra elterjedtté váló deponálása már ekkor megfigyelhető (V. SzABÓ 2004, 86; ILON 2012, 19-30).

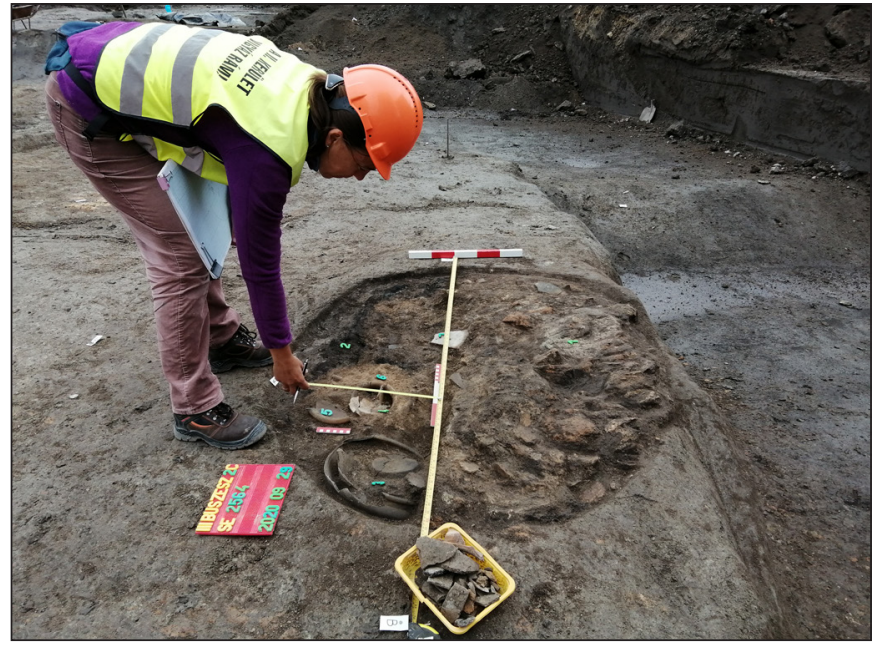

14. kép. Késő vaskori hulladékgödör dokumentálás közben (fotó: Szilas Gábor)

A Buszesz területén dokumentált késő bronzkori településrészlet fontos láncszemnek számít az urnamezős települési koncentráció rekonstruálásban. A Duna jobb partján található késő bronzkori (Kr.e. 1200-800) településhálózat részét képezik a vizsgált területtől délre, a Flórián térröl (KöSZEGI 1996) és a Harrer Pál utcából (Köszegi 1984) ismert, ikonikusnak számító kora urnamezős leletegyüttesek, valamint tőle északra a Filatorigátnál több helyen megfigyelt urnamezős telepnyomok is (ZsIDI 2001, 60). A gazdag leletanyag (grafitos bevonattal ellátott fényezett áru, rostélyos kemence, platni- és tüzikutya töredékek, nyélnyújtványos bronz kard (13. kép), nyílhegy), a gödörkomplexumok, valamint a közöttük dokumentált, az urnamezős időszakra jellemző kisméretü cölöpvázas épületek maradványai egyér- 
telmüen a magasabb nyugati térszínen csoportosulnak; a keleti magasártér zónája ebben az időszakban csak szórványos területhasználatot mutat.

A korai és középső vaskori Hallstatt-kultúra (Kr. e. 800-450) jellegzetes emlékanyagát adó, tárolóvermekből és földbe mélyített épületekből álló egységek alkotta település, hasonlóan az azt megelőző időszakhoz, egyértelműen a magasabb, II/a teraszmaradványt magában foglaló területsávra koncentrálódik. A korai és középső vaskor időszakának megtelepedési stratégiájába jól illeszkednek az itteni megfigyelések: hasonló intenzitású lelőhelyet a Duna-parti sávban északi irányban is ismerünk.

A késő vaskor időszakára az érintett partszakasz ismét teljes szélességében lakottá válik, a kelták falusias településének veremházakból, tároló- és hulladékgödrökből (14. kép) származó leletanyaga a La Tène C2-D1 (Kr. e 180-60) időszakra tehető.

\section{A katonaváros peremén}

Az Aquincum-kutatás a 2017. évi próbafeltárástól több fontos kérdésre is feleletet várt. Az elért eredmények alapján a katonaváros északkeleti negyedének beépítési határát (amely nem azonos a település közigazgatási határával!) nagy biztonsággal meg lehetett húzni az Akác közi gyárkapu és az ún. „központi csarnok” délkeleti sarka közé szerkeszthető tengely mentén (15. kép). Az is egyértelmüvé vált, hogy a másfél évszázadon át zajló gyárépítkezések nem tettek komoly kárt a római kori városi maradványokban, hiszen a déli kutatóárkokban városi házak agyag- és cementpadlós helyiségei, egy közfürdő padlófütéses termei (16. kép), valamint közmüvek láttak napvilágot igen jó állapotban. A jelenségek és a leletanyag ásatás közbeni, gyors kiértékelése alapján úgy tünik, hogy az északkeleti városrész vizsgálat alá vont sávja a 3. század utolsó harmadában elpusztult, és többé nem is épült újjá. A területhasználat azonban a 4. században sem szakadt

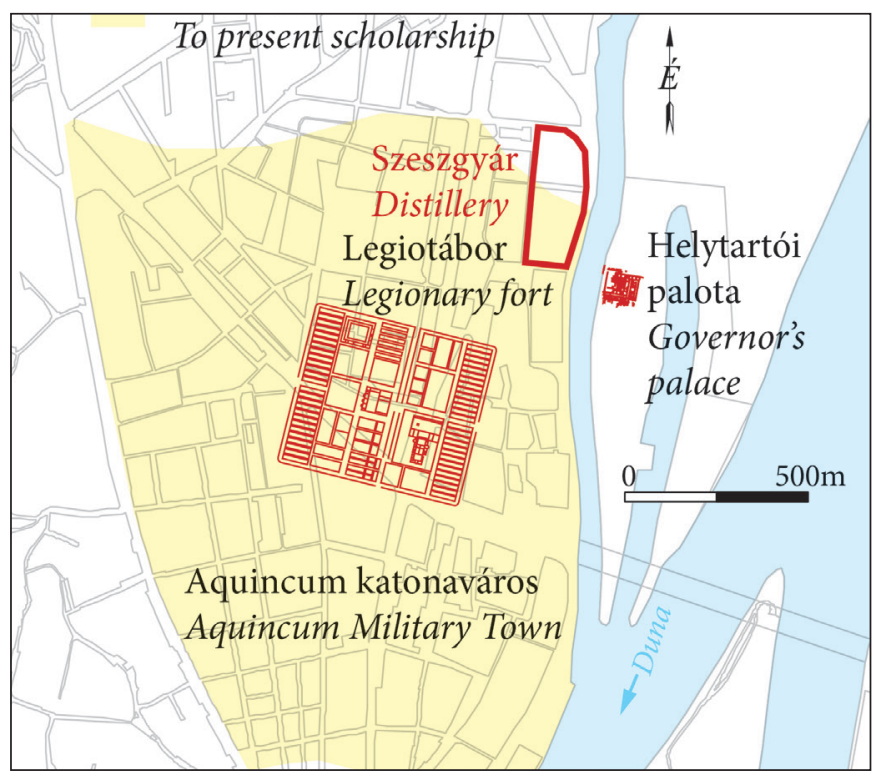

15. kép. Az egykori óbudai szeszgyár elhelyezkedése az antik topográfiára vetítve (rajz: Kolozsvári Krisztián, Budapesti

Történeti Múzeum Aquincumi Múzeuma)

meg. A felhagyott városrész épületei, kertjei - a katonaváros többi negyedében tapasztaltakhoz hasonlóan - a városközpontba visszaszoruló lakosság temetkezőhelyévé váltak. Itt a külvárosban volt a késő római kori területhasznosításnak egy egyelőre nehezen értelmezhető aspektusa is, amely az ásatáson egy mes-

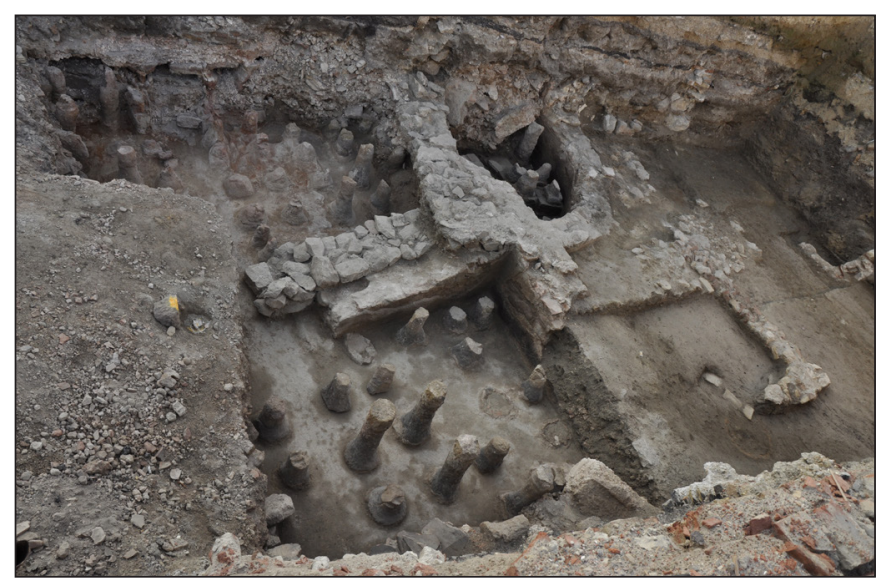

16. kép. Római közfürdö padlófütéses helyiségeinek részlete (fotó: Szilágyi Nóra, Budapesti Történeti Múzeum Aquincumi Múzeuma) terségesen visszabontott, majd feltöltött lakóépületen átvezetett, minden építési periódusnál későbbi támpilléres fal formájában jelentkezett. A Szeszgyár területének vagy szükebb környezetének katonai hasznosítását felveti, hogy a gyártelep északi térfelén elterülő temetőkben Frigeridusnak, a határvédő csapatok katonai parancsnokának (dux Valeriae ripensis: AD 371-373/374), illetve tisztikarának bélyeges téglái kerültek elő (17. kép). Nem zárható ki, hogy a tereprendezés és a támpilléres építmény emelése is kapcsolatban állt a Valentinianus-kori általános határerődítési programmal, de e kérdés biztos megválaszolása további kutatást igényel.

Amíg a gyártelep déli térfelén zajló kisfelületü szondázás csak a katonaváros legkésőbbi építési 
periódusainak kisléptékű vizsgálatát tette lehetővé, az északi térfél 2018-ban kezdődő szisztematikus feltárása a városon kívüli területhasználat teljes periodizációját ismertté tette. Három nagyméretü, félig földbemélyített ház képviseli a legkorábbi időszakot (Kr. u. 1. század vége, 2. század eleje). A vaskori életmód és lakáskultúra ellenére e házak anyaga színtisztán provinciális termékekböl áll, amely nem nélkülözi a drágább edényfajtákat sem, miközben a kelta hagyományú termékek teljesen hiányoznak a palettáról. Egy padlón heverö, összetört amphora a helyi lakosság körében meghonosodó mediterrán ízlést bizonyíthatja a gasztronómia terén is. A leletanyag teljes kiértékelése megadja majd a kis telep felhagyásának lehetséges időpontját, amely a katonaváros legkorábbi periódusának végével, a tartományi központ kiépítésének időszakával eshetett egybe.

Ezt követően a terület nyugati sávjában komoly árokrendszer és egy kútsor létesült a mezőgazdasági hasznosítás (állattartás) jegyében. A korábbi telepjelenségeket vágó árkok és a kutak betöltéséből Kr. u. 2-3. századi leletanyag került elő.

A terület keleti sávja legkésőbb a 3. század középső harmadától egy, a Kis-Duna-ág partján futó, városból kivezető főútvonal mentén észak felé nyúló temetőként funkcionált, melyet már 1868ban, a gyárépítkezés kezdetén is megbolygattak. Az eddigi megfigyeléseink alapján a temetőn belül rétegtanilag, illetve tájolás és sírtípusok alapján legalább három sírhorizont különíthető el. A legkésőbbi, 4. századi periódus gracilis csontvázai embertanilag is elütnek a korábbi robusztus népesség egyedeitöl.

A terület nyugati sávjában különálló sírcsoportok létesültek a késő római időszakban. A gyártelep északnyugati sarkában húzódó temetőrészben az egyszerü földsírok mellett részleges kőládasírok és téglasírok is elökerültek. A sírokat jellegzetes 4 . századi tárgyak - ezüstözött övcsat, hagymafejes fibulák - keltezik (18. kép). Ezt a sírcsoportot árokrendszer választja el egy délebbre húzódó, ugyancsak 4. századi temetkezőhelytől, amelyen belül legalább három sírhorizont mutatható ki. Közülük a legkorábbi hozzávetőlegesen azonos korú a keleti temető legkésőbbi sírjaival, és az ott megfigyelt gracilis alkatú népességhez köthető. A legkésőbbi sír Frigeridus dux hivatali idejéből származó bélyeges téglákból épült, mellékletei alapján nem lehet

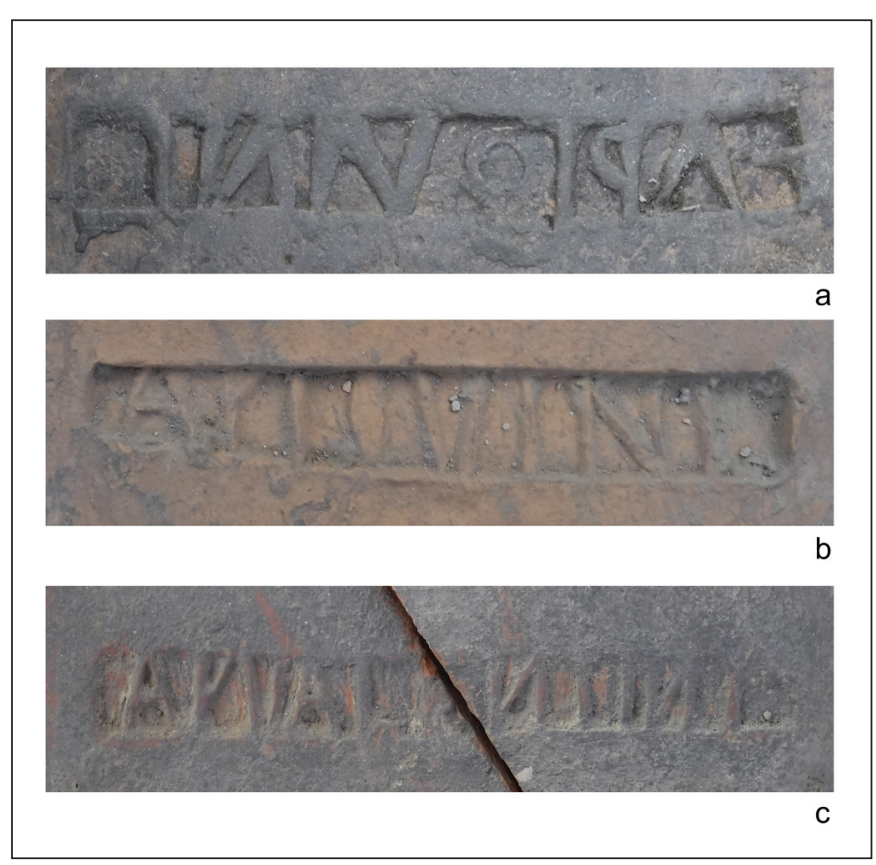

17. kép. Téglabélyegek Frigeridus dux hivatali időszakából (fotó: Budai Balogh Tibor, Budapesti Történeti Múzeum Aquincumi Múzeuma)

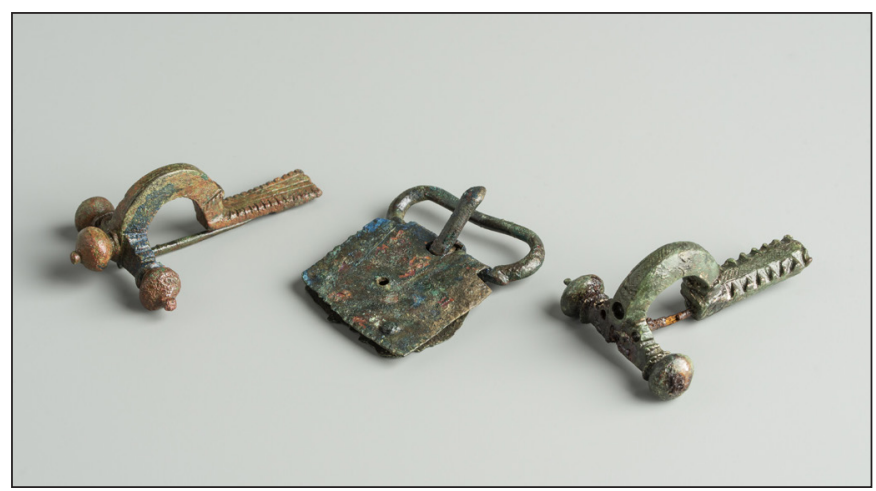

18. kép. Viseleti tárgyak a feltárási terület északnyugati sírcsoportjából (fotó: Szilágyi Nóra, Budapesti Történeti Múzeum Aquincumi Múzeuma)

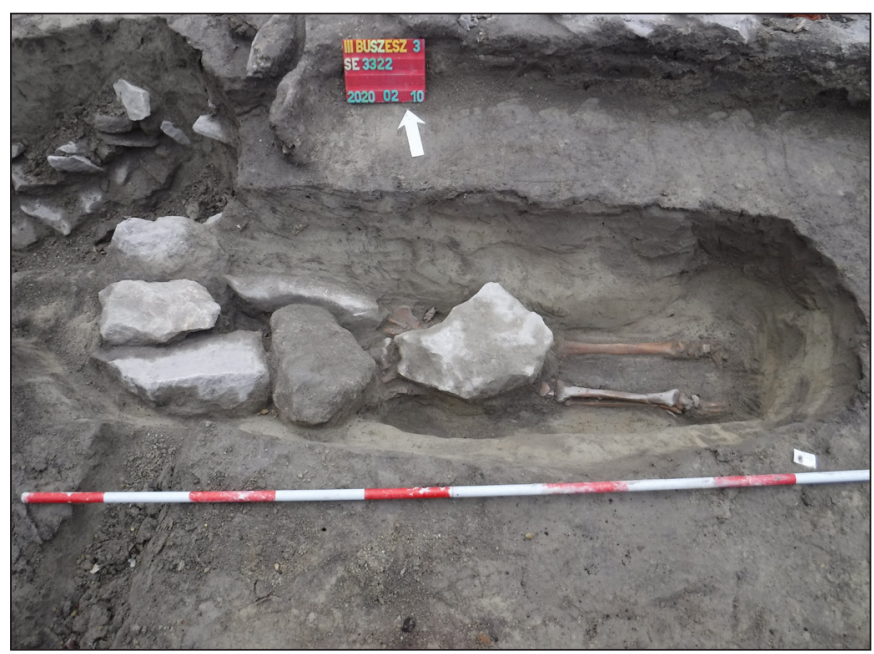

19. kép. Rendellenes temetkezések a déli sírcsoportban (fotó: Budai Balogh Tibor, Budapesti Történeti Múzeum Aquincumi Múzeuma) 
sokkal későbbi a Valentinianus-kornál. A déli sírcsoport a város irányába haladva tovább folytatódik és sürüsödik.

A szeszgyár területén ismertté vált temetőkben szokatlanul magas a kísértethittel kapcsolatos vagy büntető szándékra visszavezethető rendellenes temetkezések aránya. A kétféle szándék lényegében véve azonos eljárásokban jelentkezik: a holttest tényleges (kővel, téglával történő) vagy szimbolikus (a halottra helyezett vasszög vagy emberi koponya) lesúlyozásában, illetve a test összekötözésében (19. kép). A büntetésben részesülőket, mint kísértésre hajlamos, gonosz halottakat a „rendes emberektől” távol, a sírcsoporton kívül temették el lesúlyozva vagy összekötözve, de a kiközösítést olykor az érintett sírok eltérö tájolásával, komolyabb mélységével vagy a holttest hasra fektetésével is hangsúlyozták.

Az eddig feltárt temetörészek csak korlátozott betekintést nyújtanak az egyes sírcsoportok viszonyaiba, nagyobb léptékü temetőfeltárásra a következő ásatási idénytől nyílik lehetőség.

\section{Az Árpád-kori falu}

Mindannyiunkat meglepetésként ért a Buszesz területén napvilágra kerülö, ám az oklevelekben nem szereplő kora Árpád-kori falu részlete, mely két történeti városmag határvidékén húzódott. Aquincum ókori városának romjai még látszottak és a 11. században a középkori oklevelekben ekkor még nem régi, azaz Óbuda, hanem Buda/Budavára néven szereplő település területén is felépültek már az első nagy templomok, kőépületek. A szeszgyári építkezésekkel összefüggő 19-20. századi bolygatások miatt csak mozaikosan dokumentálható, a 4. századi temetőre is ráhúzódó falu több tucat félig földbe mélyített, téglalap alakú, átlagosan 3×2,5 m alapterületü veremházát sikerült megtalálnunk. A házak északkeleti sarkában létesítették a fütésre szolgáló kőből rakott kemencéket, melyek átboltozása két esetben épen megőrződött. Az épületek között szintén földbe mélyülő, több esetben munkagödörrel rendelkező kemencék és élelemtároló vermek szolgáltatták a viszonylag szegényes leletanyag túlnyomó hányadát. Utóbbiak közül kiemelhetőek a korszakra jellemző fazekak töredékei és egy érme, mely alapján a település a 12. században létesült.

\section{FELHASZNÁLT IRODALOM}

Budai Balogh, T. (2020). Sörgyári capriccio. Topográfiai kutatások az aquincumi canabae északkeleti határában (Capriccio in a distillery. Topographic research on the northeast border of the Aquincum canabae). Aquincumi Füzetek 24, in press.

Endrődi, A. (1992). A korabronzkori Harangedény kultúra telepe és temetője Szigetszentmiklós határában (The settlement and cemetery of the Bell-Beaker Culture in the district of Szigetszentmiklós). In Havassy P. \& Selmeczi L. (szerk.), Régészeti kutatások az M0 autópálya nyomvonalán I. - Archaeological Researches on the Line of Motorway MO Vol. 1 (pp. 83-200). BTM Mühely 5. Budapest: Budapest Történeti Múzeum.

Endrödi, A. (2001). Korabronzkori sírok Aquincum körzetében (Early Bronze Age graves in the environs of Aquincum). Aquincumi Füzetek 7, 85-88.

Endrődi, A. (2002). Adatok Békásmegyer őskori településtörténetéhez (Facts concernings the prehistoric settlement history of Békásmegyer settlements and burial-places of the Baden culture from the late Copper Age). Budapest Régiségei 35 (1), 35-75.

Fehér, G., Éry, K. \& Kralovánszky, A. (1962). A Közép-Duna-medence magyar honfoglalás és kora Árpádkori sirleletei. Leletkataszter. Régészeti Tanulmányok II. Budapest: Akadémiai Kiadó.

P. Fischl, K., Kiss, V. \& Kulcsár, G. (1999). Kora és középső bronzkori település Baks-Homokbánya (Csongrád megye) lelöhelyen. A Móra Ferenc Múzeum Évkönyve 5, 77-190. 
Szilas Gábor et al. $\bullet$ Hatezer év rétegsora

Gyuricza, A. (2008). Budapest, III., Bogdáni út - HÉV-vonal - Sorompó utca - Folyamőr utca mindkét oldala (a megszünő BUSZESZ területén kívül a Szentendrei útig húzódó lakótelep területe is) által határolt terület kerületi szabályozási tervéhez szükséges örökségvédelmi hatástanulmány régészeti fejezete. Kézirat.

Gucsi, L. \& Szabó, N. (2018). Examination and possible interpretations of a Middle Bronze Age structured deposition. Dissertationes Archaeologicae 3 (6), 217-286. https://doi.org/10.17204/dissarch.2018.217

H. Kérdő, K. \& Schweitzer F. (szerk.) (2010). Aquincum. Ókori táj - ókori város. Elmélet, módszer, gyakorlat 66. Budapest: Magyar Tudományos Akadémia Földrajztudományi Kutatóintézet.

Havas, S. (1892). Visszapillantás az 1889-1892. évek eseményeire. A főváros budai részének régi topographiája. Budapest Régiségei 4, 3-30.

Ilon, G. (2012). A halomsíros kultúra rituális „edénydepója” Veszprém határából. - The ritual „,vessel hoard" of the Tumulus culture in the vicinity of Veszprém. In Kisfaludi J. (szerk.), Régészeti kutatások Magyarországon 2010. - Archaeological Investigations in Hungary 2010 (pp. 19-53). Budapest: Kulturális Örökségvédelmi Hivatal - Magyar Nemzeti Múzeum.

Kaba, M. (1976). A Budapesti Történeti Múzeum ásatásai és leletmentései 1971-1975 között. Budapest Régiségei 24 (1), 393-444.

Kaba, M. (1984). A Budapesti Történeti Múzeum ásatásai és leletmentései 1976-1982 között. Budapest Régiségei 25, 455-502.

Kalla, G., Raczky, P. \& V. Szabó, G. (2013). Ünnep és lakoma a régészetben és az írásos forrásokban. $\mathrm{Az}$ őskori Európa és Mezopotámia példái alapján. In Déri B. (szerk.), Convivium. Az Eötvös Loránd Tudományegyetem Bölcsészettudományi Karán 2012. november 6-7-én tartott vallástudományi konferencia elöadásai (pp. 11-46). Budapest: ELTE BTK Vallástudományi Központ.

Kérdő, K. \& M. Virág, Zs. (2006). Régészeti megfigyelés az Óbudai (Hajógyári)-szigeten (Archaeological observations of Óbuda (Dockyard) Island). Aquincumi Füzetek 12, 24-29.

Kovács, T. (1978). Középső bronzkori edénylelet Mogyoródról. Archaeologiai Értesítő 105, 217-222.

Kőszegi, F. (1984). Késő bronzkori leletek a Harrer Pál utcából (Budapest, III. ker.) (Spätbronzezeitliche Funde aus der Harrer Pál utca). Budapest Régiségei 25, 121-134.

Köszegi, F. (1996). The bronze finds from Budapest-Flórián tér. In T. Kovács (Hrsg.), Studien zur Metallindustrie im Karpatenbecken und den benachbarten Regionen (pp. 175-181). Budapest: Magyar Nemzeti Múzeum.

Kőszegi, F. (2000). Öskor. In Kiss Cs. \& Mócsy F. (szerk.), Óbuda évszázadai (pp. 57-82). Budapest: Better Kiadó.

Kuzsinszky, B. (1897a). Az Aquincumi Muzeum és kőemlékei (az építészeti részek kihagyásával). Budapest Régiségei 5, 95-164.

Kuzsinszky, B. (1897b). Az aquincumi castra kérdése. Archaeológiai Értesítő 31, 395-405. 
Szilas Gábor et al. $\bullet$ Hatezer év rétegsora

Lamm, F. \& Szilas, G. (2020). Újabb kutatások az egykori BUVÁTI üdülő területén (Recent Excavations in the area of the former BUVÁTI recreational establishment. Aquincumi Füzetek 24, in press.

Nagy, G. (1904). Budapest és vidéke az öskorban. Budapest Régiségei 8, 85-157.

Nagy, L. (1937). Az Aquincumi Múzeum kutatásai és gyarapodása az 1923-35. években. Budapest Régiségei 12, 261-275.

Nagy, L. (1942). Topografia. In Szendy K. (szerk.), Budapest története. Vol. I. 2 (pp. 353-385). Budapest: Királyi Magyar Egyetemi Nyomda.

Nagy, T. (1973). Budapest története az őskortól a honfoglalásig. In Gerevich L. (szerk.), Budapest története. Vol. 1 (pp. 39-216). Budapest: Akadémiai Kiadó.

Nagy, M. (1998). Awarenzeitliche Gräberfelder im Stadtgebiet von Budapest. Vol. I. Monumenta Avarorum Archaeologica 2. Budapest: Magyar Nemzeti Múzeum - A Magyar Tudományos Akadémia Régészeti Intézete.

Póczy, K. (1983). Az aquincumi canabae utcahálózata és fontosabb épületei a II. és a III. században. Archaeológiai Értesítő 110, 252-273.

Poroszlai, I. (1992). Bölcske-Vörösgyürü. In W. Meier-Arendt (Hrsg.), Bronzezeit in Ungarn. Forschungen in Tell-Siedlungen an Donau und Theiss (pp. 141-146). Frankfurt am Main: Museum für Vor- und Frühgeschichte.

Rómer, F. (1868). A legujabb ó-budai ásatások. Archaeológiai Értesítő 1, 41-44, 65-68, 91-94.

Schreiber, R. (1967). A rákospalotai edénylelet. Archaeológiai Értesitöö 94, 54-58.

V. Szabó, G. (2004). A tiszacsegei edénydepó. Újabb adatok a Tisza-vidéki késő bronzkori edénydeponálás szokásaihoz. A Móra Ferenc Múzeum Évkönyve 10, 81-113.

Szilas, G., Viczián, I., Sipos, Gy., Páll, D. G., M. Virág, Zs. \& Rekeczki, K. (2019). Környezetrekonstrukciós vizsgálatok az óbudai Duna-part mikrorégió területén. In Tóth F. M. (szerk.), MQMO - Öskoros Kutatók XI. Összejövetele - Környezet és ember. Absztrakt kötet (p. 31). Budapest: Budapesti Történeti Múzeum.

Szilas, G. \& M. Virág, Zs. (2017). A nagy folyam vonzásában: többkorszakos őskori lelőhelyek láncolata az óbuda-békásmegyeri Duna-parton. In Zsidi P. (szerk.), Kincsek a város alatt - Újdonságok a múltból. Budapest régészeti örökségének feltárása 1867 / $2005-2015$ (pp. 21-26). Budapest: Archaeolingua.

Szilágyi, J. (1955). A rómaikori ásatások fontosabb eredményei Budapest területén és az Aquincumi Múzeum értékesebb gyarapodásai az 1951-53. években. Budapest Régiségei 15, 387-426.

Vicze, M. (2013). Middle Bronze Age Households at Százhalombatta-Földvár. In A. Anders \& G. Kulcsár (eds.), Moments in Time. Paper Presented to Pál Raczky His 60 th Birthday (pp. 757-770). Budapest: Ösrégészeti Társaság - ELTE - L’Harmattan.

Zsidi, P. (2001). Településszerkezet kutatása az aquincumi katonavárostól északra (Research into the settlement structure north of the Aquincum Military Town). Aquincumi Füzetek 7, 59-67. 